\title{
Comparison of Value Creation through M\&A in European Union
}

\author{
Karolis Andriuskevicius \\ Vilnius University, Kaunas faculty \\ Muitines st. 8, LT-44280, Kaunas, Lithuania \\ E-mail.karolis.andriuskevicius@gmail.com \\ cross $^{\text {ref }}$ http://dx.doi.org/10.5755/j01.ee.30.2.21981
}

\begin{abstract}
Mergers and acquisitions of companies are an important component of economic strategies and strategies of management of cross-border companies in changing global markets. This paper adds to the existing scientific literature by providing results of the research, which sought to compare value creation through mergers and acquisitions in the European Union. Performed research has 6 major implications. 1. Announcement of merger and acquisition transactions affects the price of shares of the acquiring company. Shareholders of the acquiring company experience a short-term increase in the value of their assets at the time of the announcement of a merger and acquisition transaction. 2. Return or loss of the price of shares of acquiring companies generated at the time of announcement of a merger and acquisition transaction may be explained not only by characteristics of the transaction or the company, but also by the attributes of the country of registration of the acquiring company. 3. Shareholders of the acquiring company experience a greater short-term increase in the value of their assets when a company, originating in a country, which acceded to the EU in 2004 and later, is acquired or merged. 4. Shareholders of the acquiring company experience a greater short-term increase in the value of their assets when merger and acquisition transactions are concluded in cross-border rather than domestic market. 5. Cultural and institutional differences between the host (inward) countries of origin generate the increase in the share price at the time of announcement of the transaction. 6. Shareholders of the acquiring company enjoy greater benefits in a common law country than shareholders of a firm of a civil law country.
\end{abstract}

Keywords: Mergers and Acquisitions; Value Creation; Event Study; European Union; Capital Market; Economic Development.

\section{Introduction}

Mergers and acquisitions of companies are an important component of economic strategies and strategies of management of cross-border companies in changing global markets. According to Thomson Reuters data, the value of global merger and acquisition transactions concluded worldwide was above USD 3.5 trillion in the United States in 2017, and exceeded USD 3 trillion for the fourth consecutive year. It is broadly inferred that value creation is the main purpose of mergers and acquisitions. Even though strategic merger and acquisition plans are mainly related to financial management prospects directly, they are an interdisciplinary dialogue between economics, accounting, book-keeping, finance, strategy, international business, law, marketing, human resources and sociology by their nature.

Various scientific disciplines examine why firms engage in merger and acquisition transactions. Most of the conducted economic studies confirm that normally, acquisitions are not beneficial to acquiring companies, but rather the acquired firms feel the greatest benefit. Nevertheless, there is a group of factors and situations (moderators) which has a positive impact on transaction results. The aim of this research is to assess the influence of different factors on the results of mergers and acquisitions and to contribute to scientific discussion in identifying the cases when mergers and acquisitions increase the value of shareholders' assets. Furthermore, it is being sought to identify the opportunities for increasing the value created by mergers and acquisitions for merging companies in the European Union. M\&A announcement effects within the
EU are chosen because, as concluded by many scholars (Mateev, 2017) the United Kingdom (UK) and Continental Europe are two of the most dynamic markets for mergers and acquisitions in the world. The tasks of the research are:

1. To create a model which describes relations and circumstances under which mergers and acquisitions are potentially beneficial for merging companies and contribute to the creation of value of shareholders' assets;

2. To perform an event study and evaluate M\&A effects on micro- and macro-levels.

\section{Theoretical Background}

The importance of mergers and acquisitions to various stakeholders (e.g. managers, employees and shareholders of the acquiring company; managers, employees and shareholders of the acquired company; existing and potential competitors of the acquiring and the acquired company; in the cross-border context of mergers and acquisitions, economic and social influence of the host (inward) country and the source (outward) country) is different, however, according to the summary made by Buckley and Ghauri (2004), they all have the fact that mergers and acquisitions can be examined from several broad perspectives in common:

1. Market for corporate control;

2. Transaction cost theory;

3. Resource-based view of the firm;

4. Influence of national and organizational cultures;

5. Processes: strategies before the announcement of mergers and acquisitions and after the announcement of the transactions, or in the course of their execution. 
Brakman et al. (2006) used in their research a detailed and extensive sample of cross-border mergers and acquisitions. Their research distinguishes relations between different theories and identifies the following key empirical characteristics of mergers and acquisitions:

1. Most foreign direct investment takes place in the form of mergers and acquisitions;

2. By participating in and concluding merger and acquisition transactions, companies pursue new markets;

3. Mergers and acquisitions take place in waves (the current wave is still developing);

4. Economic integration (international deregulation) has stimulated mergers and acquisitions;

5. The magnitude of mergers and acquisitions and the inequality between them has been increasing over time.

These stylized facts and empirical characteristics should be examined more broadly and contribute to the understanding of international economy. While some existing economic models (for example, Neary, 2003) explain some empirical characteristics, there is an apparent and clear need for a model, which could fully, comprehensively and diversely explain both the overall model of mergers and acquisitions and individual transaction characteristics.

Based on the traditional theory of economy, developed economies attract high-value investment and invest in other developed countries, as they have a similar institutional background and are affected by similar market developments. However, after economic reforms of the 1980s and 1990s, developed countries started investing in developing economies, mainly due to market potential and cheap labor force. Pandya (2016) notes that mergers and acquisitions together with foreign direct investment have become the main driving force of global economic integration, which can be characterized by generous financial support and the signing of bilateral and multilateral treaties. In light of cross-border flows and changes in the economy, identifying and choosing the preferred country for concluding a transaction is important.

Although the majority of the developed and developing countries have liberalized foreign direct investment regimes and policies, the growth of the level and activity of the merger and acquisition market represents new challenges. Caves (1987) points out that industrial organization specialists were the first ones to examine the effects of mergers and acquisitions. With market development and increasing popularity of diversifying, horizontal and vertical transactions, the number of researchers and research directions in the field has grown significantly. Mergers and acquisitions affect a wide range of countries, and this effect cannot be examined in isolation. A holistic understanding of processes and consequences of mergers and acquisitions is important to various stakeholders and areas that are directly affected by mergers and acquisitions

\section{Hypotheses of the Research}

After literature review and the assessment of the macroeconomic perspective, the following trends have been identified:

1. Merger and acquisition transactions account for a significant share in the foreign direct investment market. Macek (2012) points out that the factors affecting the direction of foreign direct investment and mergers and acquisitions are similar.

2. The choice of a particular country to engage in merger and acquisition transactions therein is affected by the political structure of the country, economic factors, and factors encouraging business development.

3. Different authors note positive (Barro, 1991; Barro \& Sala-i-Martin, 1995; Lipsey, 2002; Baliamoune-Lutz, 2004), negative (Aitken \& Harrison, 1999; etc.) and neutral (Kokko et al., 1996) effects of mergers and acquisitions on the economies of host (inward) countries.

4. Positive effects: increased productivity of domestic companies, potential economy development, decreased unemployment rate, transfer of new technologies and knowledge, collection of additional taxes for governments, support for strategies of development of individual sectors of economy, management knowledge potential, participation of domestic companies in the network of suppliers and subcontractors, better use of local infrastructure and the service sector.

5. Benefits of mergers and acquisitions are not obvious and vary widely between countries. The results of the Lin study (2008) show that the benefits of mergers and acquisitions are greater in countries with a prevailing democratic sales and investment regime, active competition policy, macro-economic stability, privatization and deregulation. The distribution of positive and negative effects depends on the economic policy in respect of mergers and distributions, the business environment and other factors.

Considering implicit theories of efficiency-, market power-, resource redistribution and the functioning of company control, main hypothesis of the research is stated as below:

H1: Shareholders of the acquiring company experience a short-term increase in the value of their assets at the time of the announcement of mergers and acquisitions.

Furthermore, additional hypotheses have been raised in order to create and test a model which describes relations and circumstances under which mergers and acquisitions are potentially beneficial for merging companies and contribute to the creation of value of shareholders' assets.

H2: Shareholders of the acquiring company experience a higher short-term increase in the value of their assets (share price increase) when a company originating in a country, which accessed the EU in 2004 and later, is acquired or merged.

H3: Shareholders of the acquiring company experience a higher short-term increase in the value of their assets (share price increase) when mergers and acquisitions take place in cross-border rather than domestic market.

H4: The greater the cultural differences between countries of origin of the acquiring and the acquired company, the higher is the return obtained at the time of the announcement of the transaction.

H5: Acquisitions between institutionally distant companies provide shareholders of acquiring companies with short-term benefits.

H6: Shareholders of the acquiring company receive greater benefits in a country of common law than shareholders of companies of civil law countries.

Figure 1 presents the quantitative model examined in the research. It consists of a dependent variable, an independent 
variable and control variables. The dependent variable is used to test the first hypothesis, mean while, independent variables represent the remaining $\mathrm{H} 2-\mathrm{H} 6$ hypotheses, which are intended for explaining the results of a merger / acquisition transaction at corporate level, i.e. the change of the price of shares of the acquiring company around the date of announcement of the transaction. Control variables aim to provide additional insights in the factors behind the changes in share prices.

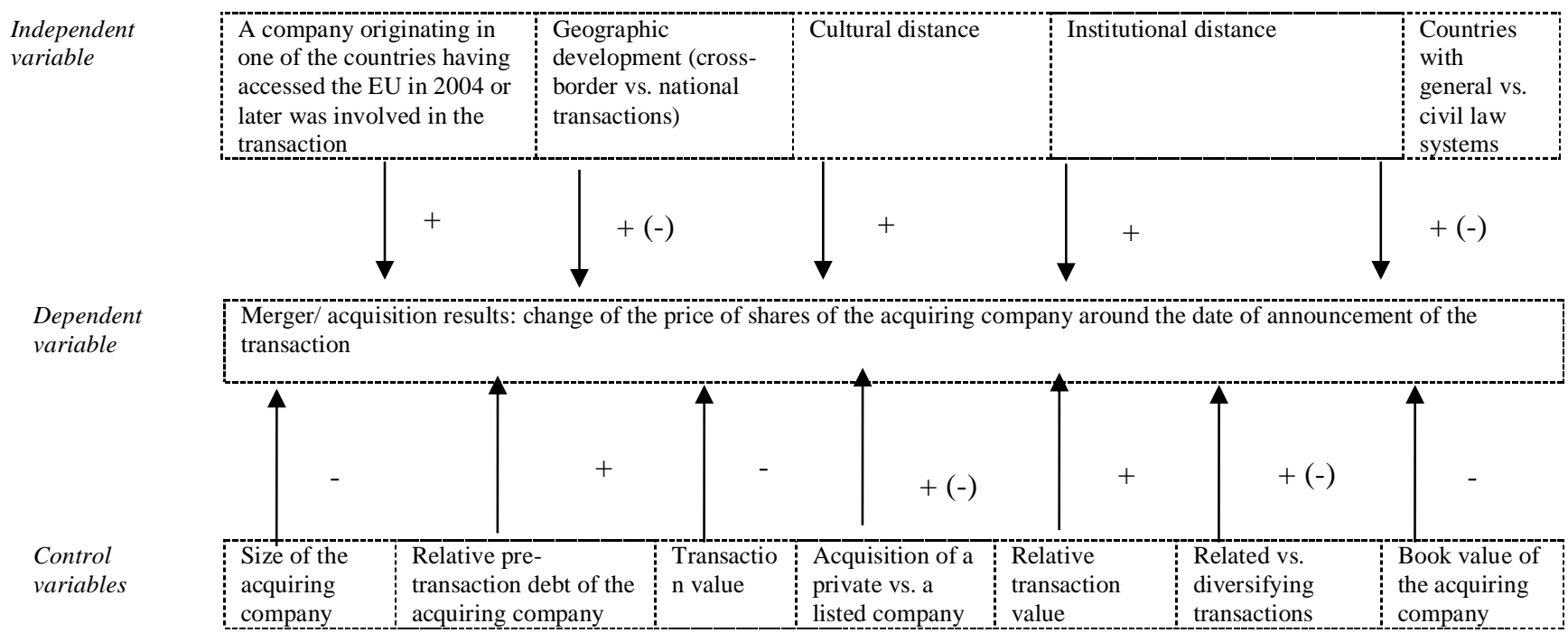

$$
\text { * Notes: } \begin{aligned}
& \text { Direction of the hypothesis } \\
& + \text { Hypothesized positive effect } \\
& - \text { Hypothesized negative effect } \\
& +(-) \text { Hypothesized positive (negative effect) }
\end{aligned}
$$

Figure 1. Quantitative Model: Relations and Circumstances under which Mergers and Acquisitions are Potentially Beneficial for Merging Companies and Contribute to the Creation of Value of Shareholders' Assets

\section{Event Study Methodology}

In order to determine if there is an abnormal share price effect related to the announcement of mergers and acquisitions, the research uses an event study methodology. Event study methodologies described by Brown and Warner (1985), MacKinley (1997) and Bruner (2002) were used to correctly conduct an event study, to calculate return received during the event and to test the hypotheses. Figure 2 presents stages of execution of the event study. The first step in conducting the event study was the collection of data on the event being analyzed. Secondly, having collected data on the analyzed event, assessment and event time slots were identified, then selecting a benchmark and methodology for calculating abnormal return. Finally, testing, parametric and non-parametric tests were conducted, and, based on the obtained values and values of parametric and non-parametric tests, interpretations were made.

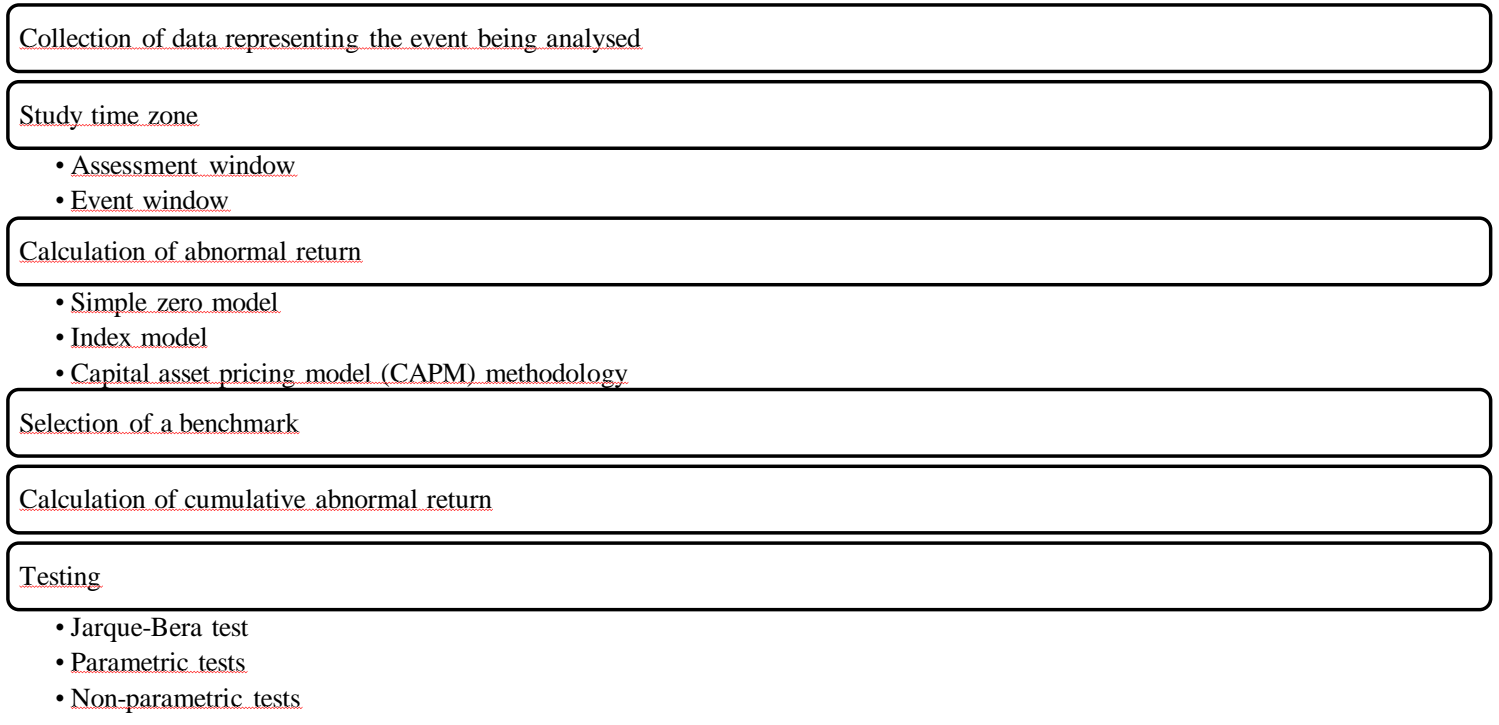

Figure 2. Stages and Methodological Provisions of the Event Study Conducted in the Research 
First of all, the basis for an event study is values of share prices of companies, which reveal the true value of companies. Results of an event study cannot be manipulated by indicators of accounting value profit, which may be distorted having chosen certain accounting procedures.

Secondly, measuring the change in the short-term value evaluates the expected current returns generated by the transaction to shareholders of companies most accurately.

Finally, the calculated share market value-based returns directly evaluate the return created to investors and offer future-oriented value creation prospects, because future cash flows are included in share prices.

The first step in conducting the event study was the identification of mergers and acquisitions. The second step identified slots of the evaluation $(-250 ;-10)$ and the event ($10 ;+30)$. Thirdly, the S\&P 350 stock index was selected as a benchmark and, based thereon and the changes in share prices of individual companies during the evaluation period, abnormal and cumulative abnormal returns were calculated. Finally, testing, parametric and non-parametric tests were carried out. The research analyzes share price changes on the day of the announcement of mergers and acquisitions, also in pre- and post-announcement periods. A homogeneous analysis, a multi-dimensional analysis and regression analysis of the least squares method were carried out.

The DataStream 5.1 database was used to identify European companies involved in mergers and acquisitions. This database allowed collecting information on transaction characteristics, merging companies and share prices of companies. The CIA World Fact Book, Eurostat, ECB, UNCTAD, Heritage Foundation and Geert Hofstede databases were used to collect information on the economies of countries. The totality of these sources formed the basis of the data used in the empirical study conducted in the research.

The prices of shares of listed European Union companies engaged in mergers and acquisitions in 2004-2017 and their changes around the time of the announcement of the transaction formed the basis of the empirical study. The DataStream 5.1. database allowed identifying that there were 3040 relevant transactions in 2004-2017, the total value of which was USD 1.394 trillion. Considering the problems encountered in the empirical study relating to obtaining daily share prices of companies, merger and acquisition transactions concluded by listed companies from Sweden, Germany and 13 European Union countries, which accessed the EU in 2004 and later, in 2004-2017, form the basis of the data used in the empirical study conducted in the research.

Importantly, when analyzing average abnormal and cumulative average abnormal returns, these shall be treated with caution because returns are only one of the attributes of the trading. As suggested by Auguets-Pratsobrerroca, Martinez-Blasco,. \& García-Blandon (2017) volatility and volume of the deals are particularly useful when M\&A news are not probably interpreted equally by all the investors, and therefore we cannot observe a direct response directly in the returns. However, this study limits itself with returns related to M\&A announcement only.

\section{Research Results}

Looking at the annual distribution of the number of merger and acquisition transactions in the European Union and the distribution of their sample of values in $2004-2017$, the following trends have been observed:

First of all, UK companies concluded 1490 transactions (49\% of all transactions in EU-28) with a total value of USD 251.7 billion (18\% of the total sample value).

Secondly, Swedish (292 transactions), French (201 transactions), Italian (186 transactions), Spanish (125 transactions) and German (121 transactions) companies together concluded $30.4 \%$ of all EU-28 transactions. It should be noted that transactions concluded by these five countries of the continental Europe together with the United Kingdom accounted for $79.4 \%$ of all mergers and acquisitions of EU-28 in the period under examination.

Thirdly, given the transaction value, companies from France $(21 \%)$, the Netherlands (15\%), Belgium $(11 \%)$, Germany (10\%) and Italy (10\%) invested in other companies for the most part. The comparison of the share of the number of mergers and acquisitions in a specific country among EU28 with the share of the value of mergers and acquisitions in a specific country among EU-28, companies from the old countries of the continental EU (France, the Netherlands, Belgium and Germany) can be concluded to be engaging in highest-value transactions.

Moreover, when comparing the distribution of domestic and cross-border transactions between countries, it should be noted that there was an average of $24 \%$ of cross-border transactions in each EU-28 country during the period under examination, while $76 \%$ were concluded domestically. However, the comparison of EU-15 and EU-13 countries revealed that EU-15 countries were more prone to engaging in cross-border transactions (24 and $19 \%$, respectively).

When it comes to EU-28 countries, private companies were acquired in $85 \%$ of transactions. Moreover, it was observed that in case of EU-13 countries, the average acquisition rate of private firms was $93 \%$, while that of EU15 was $85 \%$, which means that EU-15 countries acquire more publicly listed companies.

When comparing the market of mergers and acquisitions of companies established in EU-13 with the market of companies based in EU-15, several trends have been observed:

On one hand, EU-15 countries concluded 2841 merger and acquisition transactions with the total value of USD 1 3881 trillion (with the average value being USD 486 million). On the other hand, in cases where the acquired company originated in EU-15, 2805 transactions were concluded, with the total transaction value being USD 13718 trillion and the average transaction value - USD 489 million. This means that companies based in EU-15 tend to invest in other EU-15 companies, i.e. there is a slight difference between inward and outward investments. The ratio between the number of transactions, the total and average transaction values between inward and outward investments in the form of mergers and acquisitions is 1,013,1,007 and 0,994, respectively.

EU-13 countries concluded 199 mergers and acquisitions, with the total value of USD 13.8 billion (average value of USD 69 million). On the other hand, in cases where 
the acquired company was based in EU-13, 2355 transactions were concluded, with the total transaction value being USD 22.8 billion and the average transaction value USD 96.8 million. This means that investments reaching the companies based in EU-13 are higher than investments leaving EU-13. The number of transactions is $18 \%$ higher of inward mergers and acquisitions compared to the number of outward transactions, while the total inward transaction value is $65 \%$ and On one hand, EU-15 countries concluded 2841 merger and acquisition transactions with the total value of USD 13881 trillion (with the average value being USD 486 million). On the other hand, in cases where the acquired company originated in EU-15, 2805 transactions were concluded, with the total transaction value being USD 13718 trillion and the average transaction value - USD 489 million. This means that companies based in EU-15 tend to invest in other EU-15 companies, i.e. there is a slight difference between inward and outward investments. The ratio between the number of transactions, the total and average transaction values between inward and outward investments in the form of mergers and acquisitions is 1,013, 1,007 and 0,994, respectively.

The average transaction value paid by EU-13-based companies is more than 7 times lower than the average acquisition value of EU-15 member states and totals USD 69 million.

In the examination of EU-13-based companies, the level of activity of Polish companies can be distinguished, accounting for more than $60 \%$ of the total level of activity of EU-13 merger and acquisition market. Polish companies concluded 149 transactions with the total value of USD 5.7 billion. Meanwhile, firms investing in Polish companies concluded 146 transactions with the total value of more than USD 8.5 billion.

The Bulgarian merger and acquisition market is unique for its 2 major transactions: the acquisition of MobilTel EAD by the Austrian-based company Telekom Austria AG for USD 2.1 billion in 2004 and the acquisition of Nova Televisia by the Swedish concern Modern Times Group MTG AB for USD 967 million in 2008.

The activity of the merger and acquisition market in the EU is inevitably related to the introduction of the euro. McCarthy and Dolfsma (2015) examined 19362 acquisition transactions announced in 1990-2014 and found that the euro dramatically increased the number and value of EU mergers and acquisitions, and improved the transaction results. The authors also determined that the euro changed the geographic map of merger and acquisition market, leading to the conclusion of cross-border transactions between geographically remote companies and the preference of the acquiring companies given to the companies established in countries that had adopted the euro. It should be noted from the perspective of the international politics that the euro had a significant impact on corporate behavior and regional integration. In summary, the euro dramatically changed the structure and characteristics of the European market. Based on the research review and the comparison with the data obtained, several conclusions can be made:

a. According to Moschieri and Campa (2014), the euro has created a more liquid European capital market, which provided companies with new sources of financing. Meanwhile, Hartford (2005) found that the number of transactions has been increasing by the level of liquidity;

b. Moschieri and Campa (2014) hypothesized and argued that the introduction of the euro in a country signals the commitment of a member state to develop the EU's political and economic agenda by reducing the risk of crossing borders and increasing the predictability of future events;

c. According to Campa and Hernando (2006), the euro eliminated transaction costs associated with currency volatility, thus improving market efficiency. In other words, the euro reduced costs and risks, at the same time increasing the level of entering the market.

Similarly to the results of the study by Ficici (2018), current research results suggests that European firms' global mergers and acquisition activities increase during the beginning of financial crisis, but later the activities have slowed down. Hence, the study indicates that the effects of crisis on these firms' activities were not immediate but began recently as their activities decreased since the beginning of 2009.

Figure 3 illustrates the average abnormal (straight line) and the cumulative average abnormal (dotted line) return of the research sample in the slot of the event under examination. In the sample under examination, the announcement of a merger and acquisition transaction leads to statistically significant $6.77 \%$ increase of the value of shares of the company, on average, on the day of announcement of the transaction, while in the slot of the event under examination $(-10 ;+30)$, the average return of transactions accumulates 8.5 $\%$. Moreover, the data received show that the average abnormal returns were received for 22 out of 41 days, i.e. in $53.65 \%$ of cases. The dotted line illustrating the cumulative average abnormal return shows that the average return after the announcement of the transaction tends to retain its value.

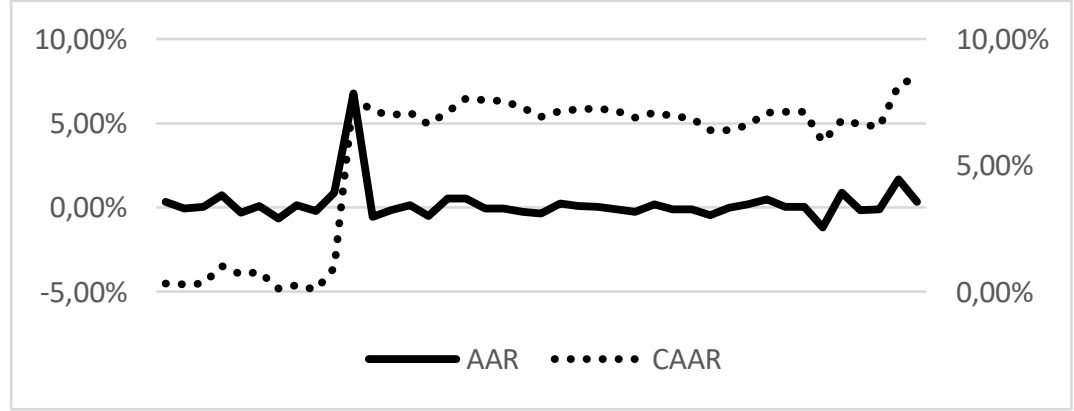

Figure 3. Research Results: Average Abnormal (AAR) and Cumulative Average Abnormal Return (CAAR) at the Time of Announcement of Mergers and Acquisitions 
Table 1 presents values and results of the assessment of the homogeneous abnormal cumulative return analysis and testing of 3 days $(-1 ; 1), 9$ days $(-10 ;-2)$ and 29 days $(+2 ;+30)$ in the event time slots.

Assessment of Cumulative Abnormal Return of 3 Days (-1; 1), 9 Days (-10; -2) and 29 Days (+2; +30)

\begin{tabular}{|c|c|c|c|c|c|c|c|}
\hline Event slot & $\begin{array}{l}\text { Average cumulative } \\
\text { abnormal return }\end{array}$ & T-test & $\begin{array}{l}\text { T-test } \\
\text { (stand) }\end{array}$ & $\begin{array}{l}\text { Jarque- } \\
\text { Beta }\end{array}$ & $\begin{array}{l}\% \text { of positive } \\
\text { transitions }\end{array}$ & $\begin{array}{l}\text { Generalized } \\
\text { sign test }\end{array}$ & Rank test \\
\hline$(-1 ;+1)$ & $7,08 \%$ & $6.58 *$ & $24.06^{*}$ & 78872.38 & $64 \%$ & $7.21^{*}$ & $7.42^{*}$ \\
\hline$(-10 ;-2)$ & $0,07 \%$ & $6.32 *$ & $27.31 *$ & 1056.53 & $50 \%$ & $2.18 * *$ & $2.03 * *$ \\
\hline$(+2 ;+30)$ & $1,35 \%$ & $1.96^{* * * *}$ & $2.86^{* * *}$ & 615.91 & $64 \%$ & 1.38 & 1.16 \\
\hline
\end{tabular}

Note: $* 1$ percent statistical significance $* * 5$ percent statistical significance $* * * 10$ percent statistical significance

Table 2 presents the results of the homogeneous analysis and testing of abnormal cumulative return of independent variables by subgroups of the sample group under examination.

Table 2

Results of the Homogeneous Analysis and Testing of Abnormal Cumulative Return of Independent Variables by Subgroups of the Sample Group under Examination

\begin{tabular}{|c|c|c|c|c|c|c|c|}
\hline \multirow{2}{*}{$\begin{array}{l}\text { Sample } \\
\text { group }\end{array}$} & \multirow{2}{*}{ Sub-group } & \multicolumn{2}{|c|}{$\begin{array}{c}\text { Examined time slot } \\
(-1 ;+1)\end{array}$} & \multicolumn{2}{|c|}{$\begin{array}{c}\text { Examined time slot } \\
(-10 ;-2)\end{array}$} & \multicolumn{2}{|c|}{$\begin{array}{c}\text { Examined time slot } \\
(+2 ;+30)\end{array}$} \\
\hline & & $\begin{array}{l}\text { Difference }^{* * *} \\
*\end{array}$ & $\begin{array}{c}\text { T- } \\
\text { test }\end{array}$ & $\underset{*}{\text { Difference }^{* * *}}$ & T-test & $\underset{*}{\text { Difference }^{* * *}}$ & T-test \\
\hline \multirow{2}{*}{ A } & $\begin{array}{l}\text { Acquired or merged company } \\
\text { originating in a country having } \\
\text { accessed the EU in } 2004 \text { or later }\end{array}$ & \multirow{2}{*}{$-2,09 \% * * *$} & \multirow{2}{*}{$-1,88$} & \multirow{2}{*}{$-0,01 \%$} & \multirow{2}{*}{-0.19} & \multirow{2}{*}{$-0,38 \% * * *$} & \multirow{2}{*}{$-1,79$} \\
\hline & $\begin{array}{l}\text { Acquired or merged company } \\
\text { originating in a country having } \\
\text { accessed the EU before } 2004\end{array}$ & & & & & & \\
\hline \multirow[t]{2}{*}{ B } & $\begin{array}{l}\text { Cross-border mergers and } \\
\text { acquisitions }\end{array}$ & \multirow[t]{2}{*}{$-1,11 \% * *$} & \multirow[t]{2}{*}{$-2,06$} & \multirow[t]{2}{*}{$0,81 \% * *$} & \multirow[t]{2}{*}{2,21} & \multirow[t]{2}{*}{$-0,01 \% * * *$} & \multirow[t]{2}{*}{1,96} \\
\hline & Domestic mergers and acquisitions & & & & & & \\
\hline \multirow{2}{*}{$\mathrm{C}$} & $\begin{array}{l}\text { Mergers and acquisitions between } \\
\text { institutionally distant firms }\end{array}$ & \multirow{2}{*}{$-3,49 \%$} & \multirow{2}{*}{-0.27} & \multirow{2}{*}{$-0,76 \%$} & \multirow{2}{*}{$-0,86$} & \multirow{2}{*}{$-1,18 \%$} & \multirow{2}{*}{$-0,26$} \\
\hline & $\begin{array}{l}\text { Mergers and acquisitions between } \\
\text { institutional close companies }\end{array}$ & & & & & & \\
\hline \multirow{2}{*}{$\mathrm{D}$} & $\begin{array}{l}\text { Acquiring or merging companies are } \\
\text { based in common law countries }\end{array}$ & \multirow{2}{*}{$-3,16 \% * * *$} & \multirow{2}{*}{$-1,93$} & \multirow{2}{*}{$0,15 \%$} & \multirow{2}{*}{0,07} & \multirow{2}{*}{$4,42 \%$} & \multirow{2}{*}{1,14} \\
\hline & $\begin{array}{l}\text { Acquiring or merging companies are } \\
\text { based in civil law countries }\end{array}$ & & & & & & \\
\hline
\end{tabular}

Note: $* 1$ percent statistical significance $* * 5$ percent statistical significance $* * * 10$ percent statistical significance $* * * *$ Difference stands for difference between cumulative average abnormal return of the sub-group sample

\section{Conclusions}

The conducted event study allows making the following conclusions on the impact of announcement of mergers and acquisitions:

Mergers and acquisitions increase the value of the acquiring company. Shareholders of the acquiring company incur a statistically important increase of the share price of $7.08 \%$ over the three-day period around the transaction date. The leak of advance information on the announcement of a transaction is not an issue. In the short-term period after the announcement of a merger and acquisition, prices of shares of the acquiring company not only retain, but also increase the share price increase created at the time of the announcement of the transaction.

Results of the research contradicts findings of Zaremba \& Plotnicki (2016) which concluded in their study of mergers and acquisitions in Central and Eastern European countries that even though announcement of a takeover creates value for both bidders and acquirers in the short run, the positive abnormal returns are decreasing while extending the time window.

A homogenous analysis of the cumulative abnormal return and independent variables at the time of announcement of mergers and acquisition revealed that both when acquiring companies originating in countries, which accessed the EU in 2004 and later, and companies originating in countries, which accessed the EU before 2004, are acquired, mergers and acquisitions generate a statistically significant share price increase return for shareholders of the acquiring company. Nevertheless, according to the results of the empirical study, contrary to the second hypothesis, shareholders of the acquiring company experience a higher short-term increase in the value of their assets when a company originating in a country having accessed the EU before 2004 is acquired or merged.

A homogeneous analysis of cumulative abnormal return and independent variables at the time of the announcement of 
mergers and acquisitions revealed that cross-border and domestic market mergers and acquisitions generate an increase in the value for companies in the short term. Nevertheless, according to the results of the independent variable analysis, contrary to the raised third hypothesis, the difference between cross-border and domestic market mergers and acquisitions is negative and statistically important.

The research hypothesized that the greater the cultural differences between the country of origin of the acquiring and the acquired company, the higher is the return obtained at the time of the announcement of the transaction. The conducted multi-dimensional cross-sectional analysis confirmed this hypothesis.

A homogenous and multi-dimensional cross-sectional analysis rendered opposite results. Mergers and acquisitions between institutionally distant companies were determined to generate short-term damage to shareholders of the acquiring firms, while mergers and acquisitions between institutionally close companies were determined to generate short-term return for shareholders of the acquiring companies.

The sixth hypothesis raised in the research is confirmed in part, because the independent variable analysis revealed that the difference in the results of mergers and acquisitions between transactions of common law countries and civil law countries was negative.

When evaluating results and implication of the research, these shall be treated with caution because, as concluded by Malhotra \& Chauhan (2018), the market response cannot be considered as the signal of future performance of acquiring company. The market response just indicates that the decision making of investors is not rational and depends upon many behavioral aspects.

\section{References}

Aitken, B., \& Harrison, A. (1999). Do Domestic Firms Benefit from Direct Foreign Investment? Evidence from Venezuela. The American Economic Review, 89(3), 605-618. https://doi.org/10.1257/aer.89.3.605

Auguets-Pratsobrerroca, X. A., Martinez-Blasco, R. L., \& Garcia-Blandon, L. J. (2017). The sixth merger wave and wealth effects of M\&A announcements: an analysis of large European bidding companies. European Accounting and Management Review. 4(1), Article 2, pp.19-48. Available at SSRN: https://ssrn.com/abstract=3080933 https://doi.org/10.26595/eamr.2014.4.1.2

Baliamoune-Lutz, M. N. (2004). Does FDI Contribute to Economic Growth? Knowledge about the Effects of FDI Improves Negotiating Positions and Reduces Risk for Firms Investing in Developing Countries. Business Economics, 39(2), 49-56.

Barro, R. (1991). Economic Growth in a Cross Section of Countries. Quarterly Journal of Economics. Vol. CVI, No. 2, pp. 407-444.https://doi.org/10.2307/2937943

Barro, R., \& Sala, M. (1995). Economic Growth. New York: McGraw-Hill, Chap. 5.

Brakman, S., Garretsen, H., \& Schramm, M. (2006). Putting new economic geography to the test: Free-ness of trade and agglomeration in the EU regions. Regional Science and Urban Economics, 36(5), 613-635.https://doi.org/10. 1016/j.regsciurbeco.2006.06.004

Brown, S., \& Warner, B. (1985). Using daily stock returns: The case of event studies. Journal of Financial Economics, 1985, 14(1), 3-31. https://doi.org/10.1016/0304-405X(85)90042-X

Bruner, R. F. (2002). Does M\&A pay? A survey of evidence for the decision maker. Journal of applied science, $12(1), 48$.

Buckley, J. P., \& Ghauri, P. N. (2004). Globalisation, economic geography and the strategy of multinational enterprises. Journal of International Business Studies, 35(2), 81-98. https://doi.org/10.1057/palgrave.jibs.8400076

Campa, J., \& Hernando, I. (2006). M\&As performance in the European financial industry. Journal of Banking \& Finance, 30(12), 3367-3392. https://doi.org/10.1016/j.jbankfin.2006.06.006

Caves, R. E. (1987). Multinational Firms, Competition and Productivity in Host-Country Markets // Economica, 41(162), 176-193. https://doi.org/10.2307/2553765

CIA World Fact Book. Available from internet: https://www.cia.gov/library/publications/download/download2017/index.html .

European Commission. Eurostat database. Available from internet: https://ec.europa.eu/eurostat/data/database.

Geert Hofstede database. Available from internet: https://www.hofstede-insights.com/country-comparison/

Heritage Foundation Database. Available from internet: https://www.heritage.org/index/explore.

Ficici, A. (2018). Econometrics analysis and application of event study methodology on international mergers and acquisition activities of MNCs from Eastern Europe. Journal of Economic and Social Thought, 5(1).

Kokko, A., Tansini, R., \& Zejan, M. C. (1996). Local Technological Capability and Productivity Spillovers from FDI in the Uruguayan Manufacturing Sector. The Journal of Development Studies. 32, 602-611. https://doi.org/10.1080/ 00220389608422430

Lin, C. H. (2008). Role of Foreign Direct Investment in Telecommunication Industries: A Developing Countries' Perspective. Contemporary Management Research. 4(1), 29-42. https://doi.org/10.7903/cmr.84 
Lipsey, R. E. (2002). Home and Host Country Effects of FDI. - Paper for ISIT Conference on Challenges to Globalization. https://doi.org/10.3386/w9293

MacKinlay, C. (1997). Event Studies in Economics and Finance. Journal of Economic Literature. Vol. XXXV (March 1997), p. 13-39

Macek, A. (2012). A Comparative Analysis of the Economic Effects of Cross-Border Mergers and Acquisitions in European Countries. International Trade from Economic and Policy Perspective. Chapter 6. Available from internet: http://dx.doi.org/10.5772/48342. https://doi.org/10.5772/48342

Malhotra, A. K., \& Chauhan, A. K. (2018). Market response of mergers and acquisitions' announcement and its predictive ability in forecasting post-merger long term performance of the acquiring company. Academy of Accounting and Financial Studies Journal. 22(2).

Mateev, M. (2017). Is the M\&A announcement effect different across Europe? More evidences from continental Europe and the UK. Research in International Business and Finance, 40, 190-216. https://doi.org/10.1016 /j.ribaf.2017.02.001

McCarthy, J. K., \& Dolfsma, W. (2015). The Euro and its Impact on the Number, Size, Performance and Regional Spread of European Mergers and Acquisitions. Journal Regional Studies. 49(8). Place-based Economic Development and the New EU Cohesion Policy. https://doi.org/10.1080/00343404.2015.1007936

Moschieri, C., \& Campa, J. M. (2014). New trends in mergers and acquisitions: Idiosyncrasies of the European market. Journal of Business Research, 67(7), 1478-1485. https://doi.org/10.1016/j.jbusres.2013.07.018

Neary, J. P. (2003). Competitive versus Comparative Advantage. The World Economy. 26(4), 457-470. https://doi.org/10.1111/1467-9701.00532

Pandya, S. S. (2016). Political economy of foreign direct investment: Globalized production in the twenty-first century. Annual Review of Political Science, 19, 455-475. https://doi.org/10.1146/annurev-polisci-051214-101237

Thomson Reuters Datastream 5.1. Available from internet: https://financial.thomsonreuters.com/en/products/toolsapplications/trading-investment-tools/datastream-macroeconomic-analysis.html .

UNCTADstat. Available from internet: http://unctadstat.unctad.org/EN/ .

Zaremba, A., \& Plotnicki, M. (2016). Mergers and acquisitions: evidence on post-announcement performance from CEE stock markets. Journal of Business Economics and Management. ISSN 1611-1699 / eISSN 2029-4433. 17(2), 251266. https://doi.org/10.3846/16111699.2015.1104384

The article has been reviewed.

Received in October 2018; accepted in April 2019. 